\title{
Synthesis, Characterization and Crystal Structure of Cobalt(II) Complex of a Schiff Base Derived from Isoniazid and Pyridine-4-Carboxaldehyde
}

\author{
Evans N. Mainsah ${ }^{1}$, Sally-Judith E. Ntum ${ }^{2}$, Mariam Asseng Conde ${ }^{3}$, George T. Chi ${ }^{4}$, \\ James Raftery ${ }^{5}$, Peter T. Ndifon ${ }^{2 *}$
}

\author{
${ }^{1}$ Department of Chemistry, Faculty of Science, University of Buea, Buea, Cameroon \\ ${ }^{2}$ Department of Inorganic Chemistry, Faculty of Science, University of Yaoundé 1, Yaoundé, Cameroon \\ ${ }^{3}$ Department of Chemistry, Faculty of Science, University of Douala, Douala, Cameroon \\ ${ }^{4}$ The School of Chemistry, De Montfort University, Leicester, UK \\ ${ }^{5}$ The School of Chemistry and the School of Materials, University of Manchester, Manchester, UK \\ Email: *pndifon@yahoo.com
}

How to cite this paper: Mainsah, E.N., Ntum, S.-J.E., Conde, M.A., Chi, G.T., Raftery, J. and Ndifon, P.T. (2019) Synthesis, Characterization and Crystal Structure of Cobalt(II) Complex of a Schiff Base Derived from Isoniazid and Pyridine-4-Carboxaldehyde. Crystal Structure Theory and Applications, 8, 45-56.

https://doi.org/10.4236/csta.2019.84004

Received: July 30, 2019

Accepted: November 26, 2019

Published: November 29, 2019

Copyright $\odot 2019$ by author(s) and Scientific Research Publishing Inc. This work is licensed under the Creative Commons Attribution International License (CC BY 4.0).

http://creativecommons.org/licenses/by/4.0/ c) (†) Open Access

\begin{abstract}
A new hydrogen bonded Cobalt(II) Schiff base complex, N'-(pyridine-4-carboxaldehyde) isonicotinoylhydrazone Cobalt(II), has been synthesized from isoniazid and pyridine-4-carboxaldehyde and characterized by IR spectroscopy, ${ }^{1} \mathrm{H}-\mathrm{NMR}$, elemental analysis, TGA and single crystal $\mathrm{X}$-ray structure determination. X-ray crystal structure analysis shows an octahedral complex with a metal centre coordinated to two ligand molecules through the pyridine nitrogen atoms and four water molecules and containing two nitrate groups as counter ions. The complex crystallizes in the monoclinic crystal system and $\mathrm{P} 2(1) / \mathrm{n}$ space group. The unit cell dimensions are: $\mathrm{a}=$ 7.2108(4) $\AA, \mathrm{b}=16.6020(9) \AA, \mathrm{c}=13.0389(6) \AA, \alpha=90^{\circ}, \beta=103.972(4)^{\circ}, \gamma=$ $90^{\circ}$. The molecule is symmetrical about the cobalt centre as observed from the ${ }^{1} \mathrm{H}-\mathrm{NMR}$ and ${ }^{13} \mathrm{C}-\mathrm{NMR}$ and confirmed by the single crystal X-ray structure of the complex. Thermogravimetric analysis shows two steps decomposition of the complex to leave a metal oxide residue. The title compound is expected to be biologically active as one of the precursors (isoniazid) is a therapeutic agent with well-established clinical applications.
\end{abstract}

\section{Keywords}

Pyridine Derivatives, Cobalt(II) Complex, Isonicotinoylhydrazone, Pyridine-4-Carboxaldehyde, Schiff Base, Heterocyclic Compound, $\mathrm{X}$-Ray Structure 


\section{Introduction}

Schiff bases display a variety of coordination modes, and have therefore attracted a lot of attention in the development of coordination Chemistry [1] [2]. The most commonly used organic connecting ligands are rigid linear bridging heterocyclic compounds such as pyrazine and 4,4'-bipyridine. However, there has been renewed interest in Schiff bases because of their varied coordination modes. The Schiff bases display varying degrees of flexibility and hence adopt different coordination modes in different complexes [3] [4] [5], the most common being the bidentate modes. Owing to their structural flexibility, tridentate [6], tetradentate [7] [8], pentadentate [9] and even hexadentate [10] coordination modes have been reported, and the flexible ligands have been employed in order to gain access to topologies not available from logical combination of rigid building blocks.

The coordination chemistry of cobalt is of considerable interest since Cobalt(II) and Cobalt(III) complexes derived from Schiff bases are reported to be biologically active [11]. The cobalt Schiff base complexes are also an important class of coordination compounds, not only because of their involvement in $\mathrm{Vi}$ tamin B12 models and oxygen carrier properties, but also due to their interesting magnetic and spectroscopic as well as diverse metal-ligand interactions [5] [12].

Heterocyclic Schiff base ligands containing $\mathrm{O}-$ or $\mathrm{N}$-donors and their metal complexes have been shown to exhibit interesting properties [11]. The study of the structural chemistry of Schiff base ligands and their complexes is important in understanding the complex biological properties of these systems.

Our group recently embarked on studies on the biological activities of complexes of heterocyclic Schiff base ligands, exploring the presence of the characteristic azomethine (-N=CH-) functionality of the Schiff base.

Intermolecular forces have played a very important role in crystal engineering especially the strong hydrogen bonds. Hydrogen bonds can effectively bind counter ions and even solvent molecules in a structure thereby contributing to the shape and supramolecular assembly of the compound. Such interactions have been found to stabilize the crystal lattice [11] [13] [14] [15] [16]. Intermolecular interactions are therefore of fundamental significance to hydrogen-bonded organic and metal-organic supramolecular structures [16]. Recently, the water content in self-assembly processes has been found to remarkably influence the structural topologies of compounds [15]. In continuation of our work on the coordination chemistry of Schiff bases derived from isoniazid, we here report on the synthesis, characterization and crystal structure of a new Cobalt(II) complex of N'-(pyridine-4-carboxaldehyde) isonicotinoylhydrazone in which bonding is through the $\mathrm{N}$-atom of pyridine, with the imine group remaining uncoordinated.

\section{Experimental}

\subsection{Materials and Method}

All chemicals and solvents used were of reagent grade. Pyridine-4-carboxaldehyde, 
isoniazid, methanol and $\mathrm{Co}\left(\mathrm{NO}_{3}\right)_{2} \cdot 6 \mathrm{H}_{2} \mathrm{O}$ were obtained from commercial sources and were used without further purification. CHN contents of the compounds were performed on FLASH 2000 Organic Elemental Analyzer, CHNS-O analyzer (thermo Scientific). Infra-Red (IR) spectroscopy was performed on a Thermo Scientific Nicolet iS5 (iDR ATR), while TGA was performed on a TGA/DSC1 STAR ${ }^{\text {e }}$ System; Mettler Toledo.

\subsection{Synthesis of the Ligand}

The ligand was synthesized by condensation between isoniazid and pyridine-4-carboxaldehyde. Isoniazid $(10.0 \mathrm{mmol}, 1.371 \mathrm{~g})$ dissolved in $10.0 \mathrm{~mL}$ of methanol on warming was added to $10.0 \mathrm{mmol}$ of pyridine-4-carboxaldehyde $(0.951 \mathrm{~mL})$ in $10.0 \mathrm{~mL}$ of methanol. The mixture was heated under reflux at about $70^{\circ} \mathrm{C}$ with continuous stirring for 4 hours as represented in Scheme 1. The volume of the solution was reduced to about half its original volume by evaporation. Pale yellow crystals were obtained on cooling. The crystals were filtered, washed with cold methanol and dried between filter paper in a desiccator.

Analysis: ${ }^{1} H$ NMR ( $\delta$ ppm): $7.69(\mathrm{~d}, \mathrm{~J}=5.87 \mathrm{~Hz}, 2 \mathrm{H}) 7.84(\mathrm{~d}, \mathrm{~J}=6.00 \mathrm{~Hz}, 2$ H) $8.47(\mathrm{~s}, 1 \mathrm{H}) 8.67(\mathrm{~d}, \mathrm{~J}=5.81 \mathrm{~Hz}, 2 \mathrm{H}) 8.81(\mathrm{~d}, \mathrm{~J}=5.94 \mathrm{~Hz}, 2 \mathrm{H}) 12.33(\mathrm{br} \mathrm{s}, 1$ $\mathrm{H}) ;{ }^{13} \mathrm{C}$ NMR $(\delta$ ppm) $121.09(s, 2 C) 121.53(s, 2 C) 140.09(s, 1 C) 141.15(s, 1$ C) $146.60(s, 1 C) 150.28(s, 2 C) 150.35(s, 2 C) 161.98(s, 1 C)$; \%; Found (\% Calculated) C: 63.71 (63.55), H: 4.46 (4.37), 24.77 (24.68).

\subsection{Synthesis of the Co(II) Complex}

The complex was synthesized by mixing the ligand and metal salt in 2:1 mole ratio respectively. The ligand $(10.0 \mathrm{mmol}, 2.263 \mathrm{~g})$, was dissolved in $10.0 \mathrm{~mL}$ of methanol/water mixture (5:5), while Cobalt(II) nitrate hexahydrate $(5 \mathrm{mmol}$, $1.455 \mathrm{~g}$ ) was dissolved in $10.0 \mathrm{~mL}$ of methanol. The two were mixed and refluxed for three hours at $70^{\circ} \mathrm{C}$. A reddish precipitate was formed, which was filtered, washed several times with absolute methanol and dried over calcium chloride in a desiccator. The filtrate was allowed to stand and reddish crystals were obtained after one week. The crystals were filtered, washed with cool methanol and dried over calcium chloride in a desiccator. Analysis: C; 40.74 (40.94), H; 3.99 (3.74), $\mathrm{N} ; 19.80$ (19.94) and Co; 8.33 (8.06).

\subsection{X-Ray Crystallographic Study}

The single crystals used in the study were selected from those obtained by slow evaporation of solvent at room temperature. A suitable reddish crystal of<smiles>NNC(=O)c1ccncc1</smiles><smiles>COc1cc(C=O)ccn1</smiles><smiles>O=C(N/N=C/c1ccncc1)c1ccncc1</smiles>

Scheme 1. Synthesis of the ligand. 
N'-(pyridine-4-carboxaldehyde) isonicotinoylhydrazone Cobalt(II) measuring about $0.21 \times 0.19 \times 0.06 \mathrm{~mm}^{3}$ was mounted using a glass fibre on the goniometer head of a Bruker APEX diffractometer and data were collected using graphite monochromated $\mathrm{Cu}-K_{\alpha}$ radiation $(\lambda=1.54178 \AA)$ at a temperature of $100 \mathrm{~K}$. The structure was solved by Direct Methods and refined by full-matrix least squares on $\mathrm{F}^{2}$ [17]. All non-Hydrogen atoms were refined anisotropically. Hydrogen atoms were included in calculated positions, assigned isotropic displacement parameters and allowed to ride on their parent carbon atoms. All calculations were carried out using the SHELXTL package [18]. Table 1 presents the crystal data and refinement parameters; Table 2 lists the selected bond lengths and bond angles while Table 3 gives the hydrogen bond parameters. CCDC 1419814

Table 1. Crystal data and structure refinement details for the Cobalt(II) complex.

\begin{tabular}{|c|c|c|}
\hline Empirical formula & $\mathrm{C} 24 \mathrm{H} 28 \mathrm{Co} \mathrm{N} 10 \mathrm{O} 12$ & \\
\hline Formula weight & 707.49 & \\
\hline Temperature & $100(2) \mathrm{K}$ & \\
\hline Wavelength & $1.54178 \AA$ & \\
\hline Crystal system & Monoclinic & \\
\hline Space group & $\mathrm{P} 2(1) / \mathrm{n}$ & \\
\hline \multirow[t]{3}{*}{ Unit cell dimensions } & $\mathrm{a}=7.2108(4) \AA$ & $\alpha=90^{\circ}$ \\
\hline & $\mathrm{b}=16.6020(9) \AA$ & $\beta=103.972(4)^{\circ}$. \\
\hline & $c=13.0389(6) \AA$ & $\gamma=90^{\circ}$. \\
\hline Volume & $1514.75(14) \AA$ & \\
\hline $\mathrm{Z}$ & 2 & \\
\hline Density (calculated) & $1.551 \mathrm{Mg} / \mathrm{m}^{3}$ & \\
\hline Absorption coefficient & $5.143 \mathrm{~mm}^{-1}$ & \\
\hline $\mathrm{F}(000)$ & 730 & \\
\hline Crystal size & $0.21 \times 0.19 \times 0.06 \mathrm{~mm}^{3}$ & \\
\hline Theta range for data collection & $4.39^{\circ}$ to $72.32^{\circ}$ & \\
\hline Index ranges & $\begin{array}{l}-8 \leq \mathrm{h} \leq 8,-20 \leq \mathrm{k} \leq 19 \\
-16 \leq 1 \leq 14\end{array}$ & \\
\hline Reflections collected & 8289 & \\
\hline Independent reflections & $2855[\mathrm{R}(\mathrm{int})=0.0363]$ & \\
\hline Completeness to theta $=67.00^{\circ}$ & $97.0 \%$ & \\
\hline Absorption correction & $\begin{array}{l}\text { Semi-empirical from } \\
\text { equivalents }\end{array}$ & \\
\hline Max. and min. transmission & 0.7478 and 0.570574 & \\
\hline Refinement method & Full-matrix least-squares on $\mathrm{F}^{2}$ & \\
\hline Data/restraints/parameters & $2855 / 0 / 234$ & \\
\hline Goodness-of-fit on $\mathrm{F}^{2}$ & 1.115 & \\
\hline Final $\mathrm{R}$ indices $[\mathrm{I}>2 \operatorname{sigma}(\mathrm{I})]$ & $\mathrm{R} 1=0.0406, \mathrm{wR} 2=0.0870$ & \\
\hline $\mathrm{R}$ indices (all data) & $\mathrm{R} 1=0.0465, \mathrm{wR} 2=0.0891$ & \\
\hline Largest diff. peak and hole & 0.327 and $-0.279 \mathrm{e} \cdot \AA^{-3}$ & \\
\hline
\end{tabular}


Table 2. Selected bond lengths/ $\AA$ and selected bond angles [ $\left.{ }^{\circ}\right]$.

\begin{tabular}{|c|c|}
\hline$C(1)-C(2)$ & $1.391(4)$ \\
\hline$C(1)-C(5)$ & $1.395(4)$ \\
\hline$C(1)-C(6)$ & $1.456(3)$ \\
\hline$C(2)-C(3)$ & $1.377(4)$ \\
\hline $\mathrm{C}(12)-\mathrm{H}(12)$ & 0.9500 \\
\hline $\mathrm{Co}(1)-\mathrm{O}(5)$ & $2.0465(17)$ \\
\hline $\mathrm{Co}(1)-\mathrm{O}(5) \# 1$ & $2.0465(17)$ \\
\hline $\mathrm{Co}(1)-\mathrm{O}(6)$ & $2.1117(17)$ \\
\hline $\mathrm{Co}(1)-\mathrm{O}(6) \# 1$ & $2.1118(17)$ \\
\hline $\mathrm{Co}(1)-\mathrm{N}(4)$ & $2.1743(19)$ \\
\hline $\mathrm{Co}(1)-\mathrm{N}(4) \# 1$ & $2.1743(19)$ \\
\hline $\mathrm{N}(2)-\mathrm{N}(3)$ & $1.376(3)$ \\
\hline $\mathrm{N}(3)-\mathrm{H}(3 \mathrm{~B})$ & $0.79(4)$ \\
\hline $\mathrm{O}(6)-\mathrm{H}(6 \mathrm{~A})$ & $0.84(4)$ \\
\hline $\mathrm{O}(6)-\mathrm{H}(6 \mathrm{~B})$ & $0.78(4)$ \\
\hline $\mathrm{N}(2)-\mathrm{C}(6)-\mathrm{C}(1)$ & $121.8(2)$ \\
\hline $\mathrm{N}(2)-\mathrm{C}(6)-\mathrm{H}(6)$ & 119.1 \\
\hline $\mathrm{C}(7)-\mathrm{N}(3)-\mathrm{N}(2)$ & $120.0(2)$ \\
\hline $\mathrm{C}(7)-\mathrm{N}(3)-\mathrm{H}(3 \mathrm{~B})$ & $123(3)$ \\
\hline $\mathrm{Co}(1)-\mathrm{O}(5)-\mathrm{H}(5 \mathrm{~A})$ & $122(3)$ \\
\hline $\mathrm{H}(5 \mathrm{~B})-\mathrm{O}(5)-\mathrm{H}(5 \mathrm{~A})$ & $109(3)$ \\
\hline $\mathrm{Co}(1)-\mathrm{O}(6)-\mathrm{H}(6 \mathrm{~A})$ & $125(2)$ \\
\hline $\mathrm{Co}(1)-\mathrm{O}(6)-\mathrm{H}(6 \mathrm{~B})$ & $117(3)$ \\
\hline $\mathrm{H}(6 \mathrm{~A})-\mathrm{O}(6)-\mathrm{H}(6 \mathrm{~B})$ & $113(3)$ \\
\hline
\end{tabular}

Table 3. Hydrogen bonds [ $\left[\AA\right.$ and $\left.{ }^{\circ}\right]$.

\begin{tabular}{ccccc}
\hline $\mathrm{D}-\mathrm{H} \ldots \mathrm{A}$ & $\mathrm{d}(\mathrm{D}-\mathrm{H})$ & $\mathrm{d}(\mathrm{H} \ldots \mathrm{A})$ & $\mathrm{d}(\mathrm{D} \ldots \mathrm{A})$ & $<(\mathrm{DHA})$ \\
\hline $\mathrm{O}(5)-\mathrm{H}(5 \mathrm{~B}) \ldots \mathrm{O}(3)$ & $0.88(4)$ & $1.89(4)$ & $2.767(3)$ & $178(4)$ \\
$\mathrm{O}(6)-\mathrm{H}(6 \mathrm{~A}) \ldots \mathrm{O}(1) \# 2$ & $0.84(4)$ & $1.98(4)$ & $2.793(3)$ & $163(4)$ \\
$\mathrm{O}(6)-\mathrm{H}(6 \mathrm{~B}) \ldots \mathrm{O}(3) \# 3$ & $0.78(4)$ & $2.01(4)$ & $2.789(3)$ & $178(4)$ \\
$\mathrm{O}(6)-\mathrm{H}(6 \mathrm{~B}) \ldots \mathrm{N}(5) \# 3$ & $0.78(4)$ & $2.69(4)$ & $3.417(3)$ & $156(3)$ \\
$\mathrm{O}(5)-\mathrm{H}(5 \mathrm{~A}) \ldots \mathrm{N}(1) \# 4$ & $0.83(4)$ & $1.89(4)$ & $2.724(3)$ & $174(4)$ \\
$\mathrm{N}(3)-\mathrm{H}(3 \mathrm{~B}) \ldots \mathrm{O}(4) \# 2$ & $0.79(4)$ & $2.37(4)$ & $3.118(3)$ & $160(3)$ \\
$\mathrm{N}(3)-\mathrm{H}(3 \mathrm{~B}) \ldots \mathrm{O}(2) \# 2$ & $0.79(4)$ & $2.50(4)$ & $3.114(3)$ & $137(3)$ \\
\hline
\end{tabular}

Symmetry transformations used to generate equivalent atoms: $\# 1-x,-y+1,-z+1 ; \# 2 x-1 / 2,-y+3 / 2, z$ $-1 / 2 ; \# 3-\mathrm{x}+1,-\mathrm{y}+1,-\mathrm{z}+1 ; \# 4 \mathrm{x}, \mathrm{y}-1, \mathrm{z}$.

contains the supplementary crystallographic data for the title compound. This data can be obtained from the Cambridge Crystallographic Data Centre via $\underline{\text { www.ccdc.cam.ac.uk/dada_request/cif. }}$ 


\section{Results and Discussion}

The Schiff base ligand was prepared by reacting one mole of isoniazid with one mole of the pyridine-4-carboxaldehyde in methanol as solvent. The air stable ligand, N'-(pyridine-4-carboxaldehyde) isonicotinoylhydrazone was obtained as a cream coloured powder. The complex which was precipitated from a 2:1 ligand to metal ratio in a water-methanol mixture is stable in air. The elemental analysis data show close agreement between the experimental and calculated values. The close agreement of the experimental and calculated values is indicative of the purity of the compounds as well as agreement with the proposed structure.

\subsection{Spectroscopic Analyses}

The IR spectrum of the ligand shows a strong absorption band at $3191 \mathrm{~cm}^{-1}$, attributed to the $\mathrm{N}-\mathrm{H}$ vibration, while the bands at $3005 \mathrm{~cm}^{-1}, 1682 \mathrm{~cm}^{-1}$ and 1569 $\mathrm{cm}^{-1}$, assigned to $\mathrm{C}-\mathrm{H}, \mathrm{C}=\mathrm{O}, \mathrm{C}=\mathrm{N}$ stretching respectively [6] [19] [20]. The occurrence of the $\mathrm{N}-\mathrm{H}$ and $\mathrm{C}=\mathrm{N}$ vibrations show that the ligand has actually been formed. Also, the presence of the $\mathrm{C}=\mathrm{N}$ vibration in the spectrum confirms that the ligand occurs in the imine form and not the enol form. The Co(II) complex displays an absorption band at $3349 \mathrm{~cm}^{-1}$, which was not present in the ligand. This band is assigned to the $\mathrm{O}-\mathrm{H}$ stretching of coordinated water [15], suggesting the presence of coordinated water in the complex. This band merges with the $\mathrm{N}-\mathrm{H}$ stretching which occurs at $3230 \mathrm{~cm}^{-1}$. This band is broad, indicating the existence of hydrogen bonding interactions in the molecules. The $\mathrm{C}=\mathrm{O}$ band in the complex occurs at slightly lower wavenumber, that is $1675 \mathrm{~cm}^{-1}$ while the $\mathrm{C}=\mathrm{N}$ band occurs at $1556 \mathrm{~cm}^{-1}$. The carbonyl oxygen and azomethine nitrogen atoms do not take part in coordination. The slight shift in wavenumber for the $\mathrm{C}=\mathrm{O}$ stretching in the complex could be attributed to the involvement of the carbonyl oxygen in intermolecular hydrogen bonding with the nitrate ion in the crystal lattice.

Figure 1 shows the ${ }^{1} \mathrm{H}-\mathrm{NMR}$ spectrum of $\mathrm{L} 3$ which was recorded in DMSO- $d_{6}$ at $400 \mathrm{MHz}$. A broad peak observed in the $12.20-12.24 \mathrm{ppm}$ range can be attributed to the N-H proton (H9). The azomethine singlet protons observed in the range $8.48-8.51 \mathrm{ppm}(\mathrm{H} 7)$ are less deshielded compared to the singlet (H2) of the pyridine moiety of the ligand. This can be due to resonance effect of the ring. Six peaks are observed in the spectrum of this ligand due to the presence of four pairs of chemically equivalent protons ( $\mathrm{H} 1$ and $\mathrm{H} 4, \mathrm{H} 3$ and $\mathrm{H} 6, \mathrm{H} 12$ and H13, H14 and H15).

\subsection{Thermal Analysis}

The TGA thermogram of $\left[\mathrm{Co}(\mathrm{L} 3)_{2}\left(\mathrm{H}_{2} \mathrm{O}\right)_{4}\right]\left(\mathrm{NO}_{3}\right)_{2}$ recorded under an $\mathrm{N}_{2}$ atmosphere, in the temperature range of $25^{\circ} \mathrm{C}$ to $600^{\circ} \mathrm{C}$ at a heating rate of $25^{\circ} \mathrm{C} \cdot \mathrm{min}^{-1}$ and shown in Figure 2 displays a two-step decomposition pattern of the complex. The first weight loss between $95^{\circ} \mathrm{C}$ and $193^{\circ} \mathrm{C}$ can be assigned to the 


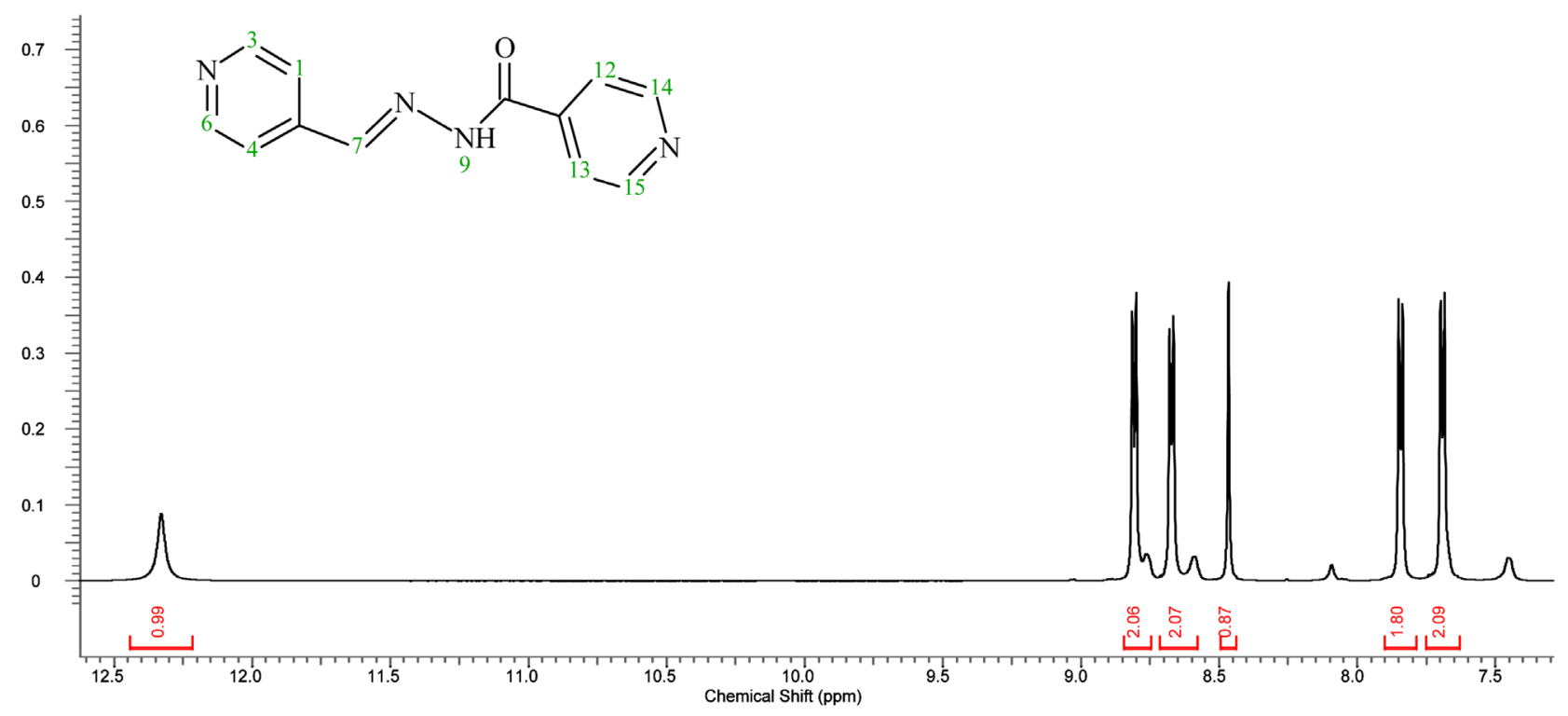

Figure 1. ${ }^{1} \mathrm{H}$ NMR spectrum of N'-(pyridine-4-carboxaldehyde) isonicotinoylhydrazone.

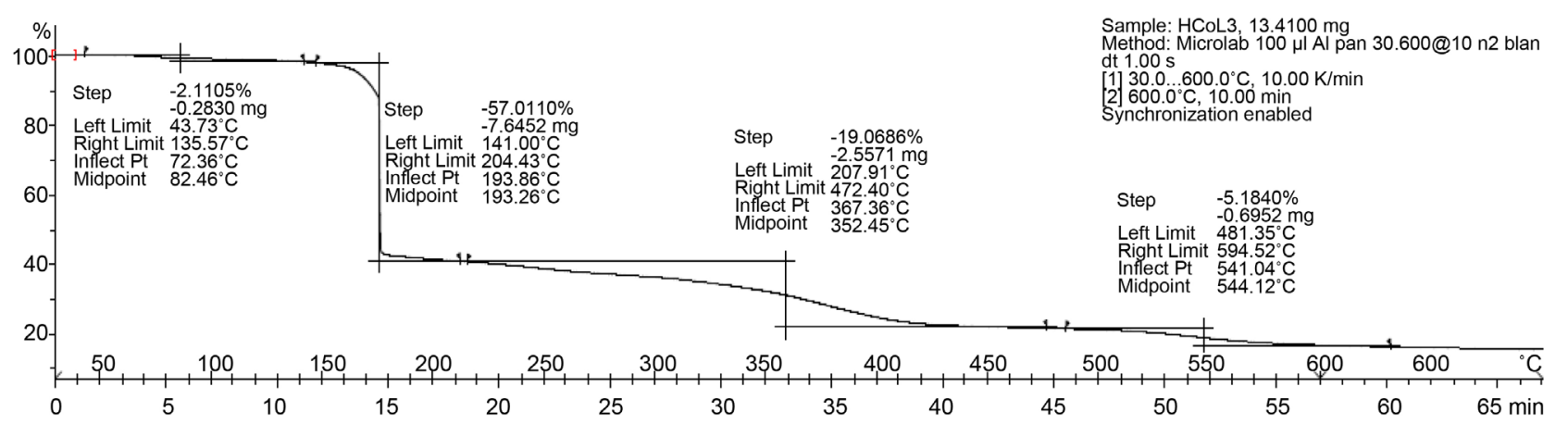

Figure 2. TGA thermogram of N'-(pyridine-4-carboxaldehyde) isonicotinoylhydrazone Cobalt(II).

decomposition of the Schiff base ligands (64.6 (calc. 63.9\%)). The second step observed between $352^{\circ} \mathrm{C}$ and $530^{\circ} \mathrm{C}$ shows a mass loss of $26.6 \%$ (calc. $27.7 \%$ ) corresponding to the decomposition of the two nitrate groups and the coordinated water molecules. This leaves a $\mathrm{CoO}$ residue which represents $13.14 \%$ (calc. $12.88 \%)$ of the mass.

\subsection{Crystal and Molecular Structure}

The complex crystallizes in the monoclinic crystal system and $\mathrm{P} 2(1) / \mathrm{n}$ space group and contains two molecules in the unit cell. The significant bond lengths and bond angles are given in Table 2. The ORTEP drawing of the complex showing the coordination geometry is shown in Figure 3 while the packing diagram is presented in Figure 4.

The molecular structure of the complex reveals a six coordinate octahedral Cobalt(II) centre. Two ligands are coordinated to the Cobalt(II) centre while the remaining coordination sites are occupied by four water molecules as shown in Figure 3. The Co-O bond lengths (2.0465 - $2.1118 \AA$ ) are shorter than the Co-N 


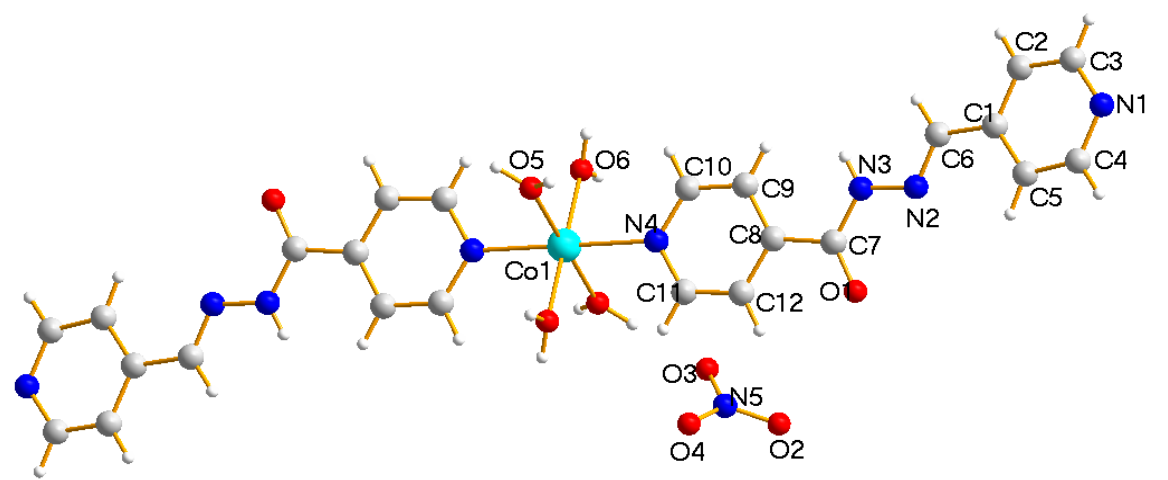

Figure 3. ORTEP diagram of N'-(pyridine-4-carboxaldehyde) isonicotinoylhydrazone Cobalt(II).
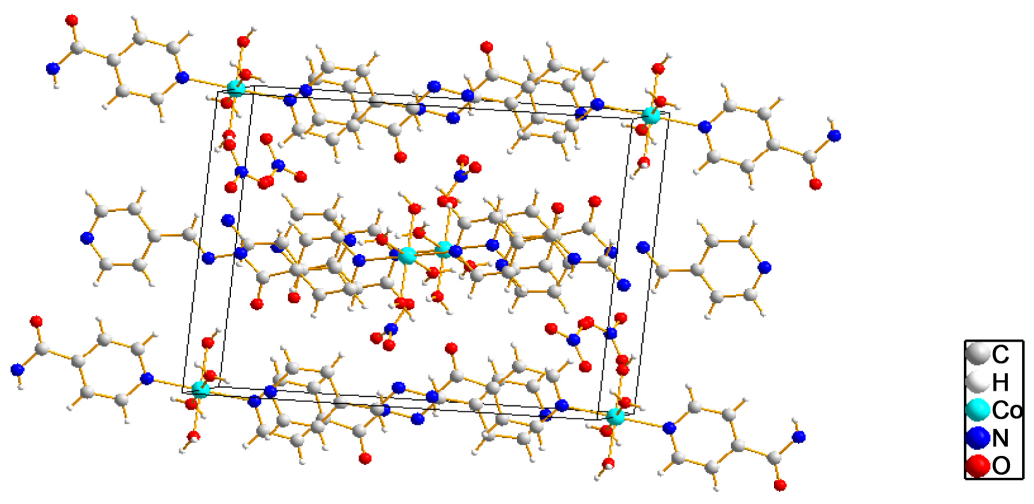

(a)

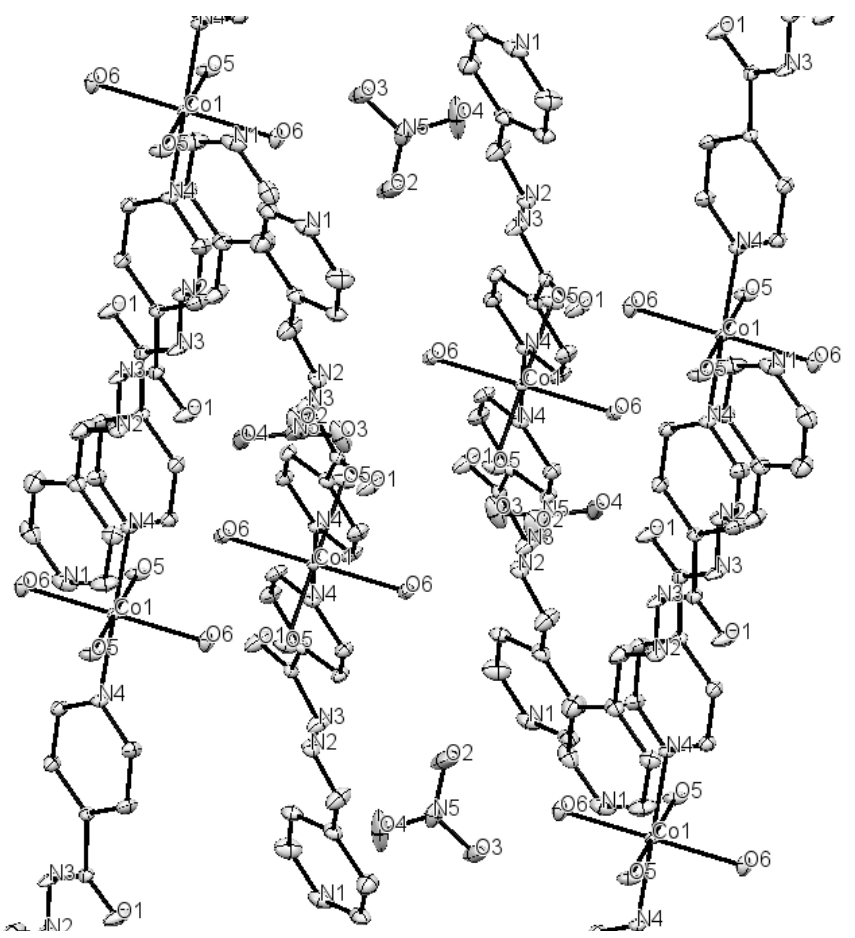

(b)

Figure 4. Packing diagrams of $\mathrm{N}^{\prime}$-(pyridine-4-carboxaldehyde) isonicotinoylhydrazone Cobalt(II). 
bond lengths $(2.1743 \AA$ ) in the complex. The Co-O bond lengths in the complex differ a little from one another. This indicates a slight distortion in the octahedral geometry [16]. The Co- $\mathrm{N}[\mathrm{Co}(1)-\mathrm{N}(4)$ is 2.1743(19) $\AA, \operatorname{Co}(1)-\mathrm{N}(4) \# 1$ is 2.1743(19) $\AA$ ] bond lengths are shorter than those reported elsewhere [11] for similar types of complexes. Also, the N-N (N(2)-N(3) is 1.376(3) $\AA$, which is shorter than the N-N bond length of similar compounds.

The $\mathrm{O}(5)-\mathrm{Co}(1)-\mathrm{O} \# 1, \mathrm{O}(6)-\mathrm{Co}(1)-\mathrm{O}(6) \# 1, \mathrm{~N}(4)-\mathrm{Co}(1)-\mathrm{N}(4) \# 1$ are perfectly linear with bond angles of $180^{\circ}$. The bite angles $\mathrm{O}(5)-\mathrm{Co}(1)-\mathrm{O}(6) ; 90.39^{\circ}(7)$, $\mathrm{O}(5) \# 1-\mathrm{Co}(1)-\mathrm{O}(6) ; 89.61^{\circ}(7), \mathrm{O}(5)-\mathrm{Co}(1)-\mathrm{O}(6) \# 1 ; 89.61^{\circ}(7)$;

$\mathrm{O}(5) \# 1-\mathrm{Co}(1)-\mathrm{O}(6) \# 1 ; 90.39^{\circ}(7), \mathrm{O}(5)-\mathrm{Co}(1)-\mathrm{N}(4) ; 89.73^{\circ}(7)$,

$\mathrm{O}(5) \# 1-\mathrm{Co}(1)-\mathrm{N}(4) ; 90.27^{\circ}(7), \mathrm{O}(6)-\mathrm{Co}(1)-\mathrm{N}(4) ; 92.47^{\circ}(7), \mathrm{O}(6) \# 1-\mathrm{Co}(1)-\mathrm{N}(4)$;

$87.53^{\circ}(7), \quad \mathrm{O}(5)-\mathrm{Co}(1)-\mathrm{N}(4) \# 1 ; \quad 90.27^{\circ}(7), \quad \mathrm{O}(5) \# 1-\mathrm{Co}(1)-\mathrm{N}(4) \# 1 ; \quad 89.73^{\circ}(7)$, $\mathrm{O}(6)-\mathrm{Co}(1)-\mathrm{N}(4) \# 1 ; 87.53^{\circ}(7), \mathrm{O}(6) \# 1-\mathrm{Co}(1)-\mathrm{N}(4) \# 1 ; 92.47^{\circ}(7)$ are all very close to $90^{\circ}$, revealing the least distortion of the octahedral geometry. This geometry observed in this complex is similar to that of other compounds reported elsewhere [12]. The distortion around the metal centre is negligible hence the complex is symmetric about the metal centre. The packing diagram, Figure 4(a), shows intermolecular hydrogen bonding between the pyridine nitrogen of one monomer and hydrogen of coordinated water of another monomer on the one hand and between oxygen of the nitrate group and hydrogen of coordinated water on the other hand.

The intermolecular hydrogen bond interactions in the complex are presented in Table 3. The intermolecular hydrogen bond interaction between the $\mathrm{C}=\mathrm{O}$ of one monomer and the pyridine nitrogen atom of another monomer $\mathrm{O}(5)-\mathrm{H}(5 \mathrm{~A}) \ldots \mathrm{N}(1) \# 4$ as well as the hydrogen bond interactions between the coordinated water molecules of one monomer with the oxygen atom of the nitrate group $\mathrm{O}(6)-\mathrm{H}(6 \mathrm{~B}) \ldots \mathrm{O}(3) \# 3$ lead to self-assembly of monomeric cores to form a supramolecular structure as presented in the packing diagram in Figure 4(b). The monomer of one complex therefore is linked to the monomer of another complex through intermolecular hydrogen bonding, involving coordinated water ligands and uncoordinated nitrates as shown in Figure 5. This kind of interaction is found to stabilize the structure [16].

\section{Conclusion}

We have reported here, the isolation of a Cobalt(II) complex of a pyridine-containing heterocyclic Schiff base ligand. The complex shows negligible distortion of the octahedral geometry. Unlike in many Schiff base complexes which coordinate to the metal through the azomethine nitrogen and carbonyl oxygen atoms, the Schiff base in this case is found to coordinate to the metal through the pyridine nitrogen, forming a perfectly linear "head to head" $\mathrm{N}-\mathrm{Co}-\mathrm{N}$ system, with the imine (-N=CH-) groups remaining unusually uncoordinated. The molecule is symmetrical about the cobalt centre as observed from the ${ }^{1} \mathrm{H}$-and ${ }^{13} \mathrm{C}$-NMR and confirmed by the X-ray structure of the complex. 


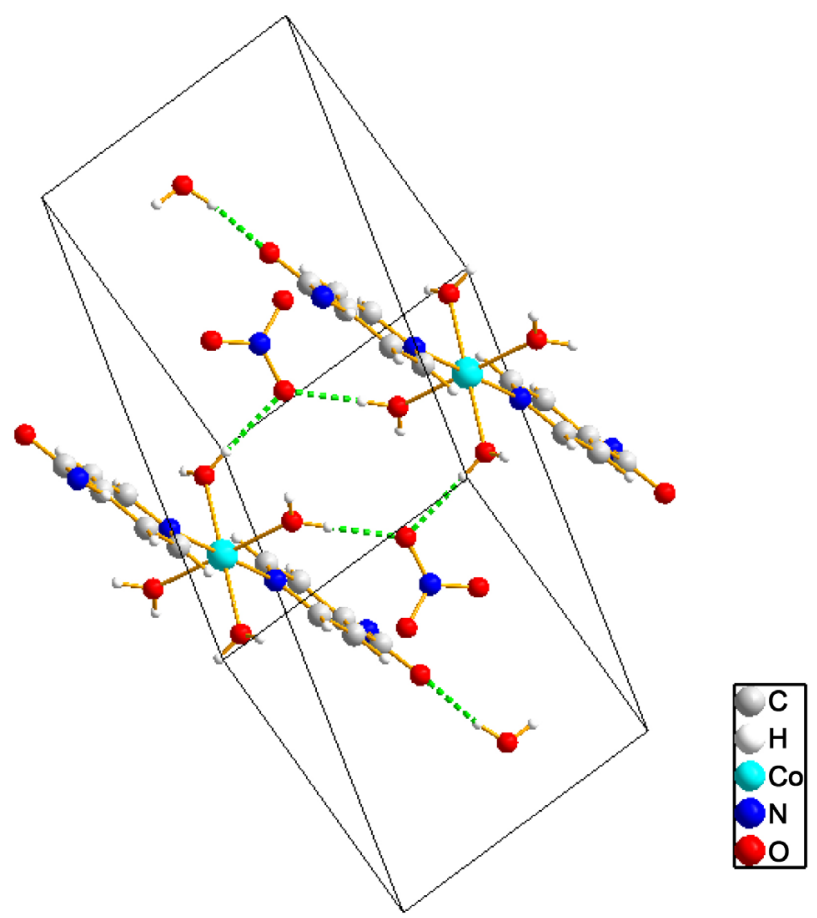

Figure 5. ORTEP drawing unit cell and hydrogen bonding in N'-(pyridine-4-carboxaldehyde) isonicotinoylhydrazone Cobalt(II).

Isoniazid (one of the precursors), is a therapeutic agent with established clinical applications. Compounds of similar backbone have shown antibacterial, antifungal and anti-onchocercal activities. Studies would be extended to the biological properties of the title compound.

\section{Acknowledgements}

The authors thank the RS-DFID capacity building initiative for mobility bursary to (NS-JE).

\section{Conflicts of Interest}

The authors declare that there is no conflict of interest regarding the publication of this paper.

\section{References}

[1] Qurban, S.W. (2011) Synthesis and Characterization of Some Transition Metal Complexes of Schiff Bases Derived from Isonicotinic Hydrazide and O-Vanillin. Diyala Journal for Pure Sciences, 7, 94-104.

[2] Kajal, A., Bala, S., Kamboj, S., Sharma, N. and Saini, V. (2013) Schiff Bases: A Versatile Pharmacophore. Journal of Catalysts, 2013, Article ID: 893512. https://doi.org/10.1155/2013/893512

[3] Amirnasr, M., Mahmoudkhani, A.H., Gorji, A., Dehghanpour, S. and Bijanzade, H.R. (2002) Cobalt(II), Nickel(II), and Zinc(II) Complexes with Bidentate N,N'-Bis(b-Phenylcinnamaldehyde)-1,2-Diiminoethane Schiff Base: Synthesis and 
Structures. Polyhedron, 21, 2733-2742. https://doi.org/10.1016/S0277-5387(02)01277-9

[4] Akitsu, T. and Einaga, Y. (2006) Synthesis and Crystal Structures of the Flexible Schiff Base Complex Bis(N-1,2-Diphenylethyl-Salicydenaminato- $\left.\kappa^{2} \mathrm{~N}, \mathrm{O}\right)$ Copper(II) (Methanol): A Rare Case of Solvent-Induced Distortion. Polyhedron, 25, 1089-1095. https://doi.org/10.1016/j.poly.2005.07.048

[5] Nica, S., Rudolph, M., Lippold, I., Buchholz, A., Görls, H. and Plass, W. (2015) Vanadium(V) Complex with Schiff-Base Ligand Containing a Flexible Amino Side Chain: Synthesis, Structure and Reactivity. Journal of Inorganic Biochemistry, 147, 193-203. https://doi.org/10.1016/j.jinorgbio.2015.02.009

[6] Elif, G., Selma, C., Dilek, A. and Hulya, K. (2012) Two Tridentate Schiff Base Ligands and Their Mononuclear Cobalt (III) Complexes: Synthesis, Characterization, Antibacterial and Antifungal Activities. Spectrochimica Acta Part A: Molecular and Biomolecular Spectroscopy, 94, 216-221. https://doi.org/10.1016/j.saa.2012.03.034

[7] Maher, K.A. and Mohammed, S.R. (2015) Metal Complexes of Schiff Base Derived From Salicylaldehyde-A Review. International Journal of Current Research and Review, 7, 6-16.

[8] Prasanta, B. and Drew, M.G.B. (2011) Synthesis and Characterization of Nickel(II) and Copper(II) Complexes with Tetradentate Schiff Base Ligands. Inorganica Chimica Acta, 366, 62-67. https://doi.org/10.1016/j.ica.2010.10.010

[9] Chandra, S., Jain, D., Sharma, A.K. and Sharma, P. (2009) Coordination Modes of a Schiff Base Pentadentate Derivative of 4-Aminoantipyrine with Cobalt(II), Nickel(II) and Copper(II) Metal Ions: Synthesis, Spectroscopic and Antibacterial Studies. Molecules, 14,174-190. https://doi.org/10.3390/molecules14010174

[10] Xiang, L. and Jean-René, H. (2019) Recent Developments in Penta-, Hexa- and Heptadentate Schiff Base Ligands and Their Metal Complexes. Coordination Chemistry Reviews, 389, 94-118. https://doi.org/10.1016/j.ccr.2019.03.010

[11] Sasi, S., Kurup, M.R.P. and Suresh, E. (2006) Synthesis and Crystal Structure of Cobalt(III) Complex with a Schiff Base and Azide. Journal of Chemical Crystallography, 37, 31-36. https://doi.org/10.1007/s10870-006-9087-3

[12] Khan, S., Bhar, K., Roy, S., Ramachandran, K. and Ghosh, B.K. (2011) Synthesis, Structures and Molecular Properties of Two Mononuclear Cobalt(III) Halide Complexes Containing a Tetradentate N-Donor Schiff Base. Indian Journal of Chemistry, 50A, 1429-1435.

[13] Solange, M.S.V.W., de Souza, M.V.N., James, L.W., John, N.L. and Christopher, G. (2007) Three Isomeric 1-(2-Chloronicotinoyl)-2-(Nitrophenyl) Hydrazines, Including Three Polymorphs of 1-(2-Chloronicotinoyl)-2-(2-Nitrophenyl) Hydrazine: Hydrogen-Bonded Supramolecular Structures in Two and Three Dimensions. Acta Crystallographica, B63, 101-110. https://doi.org/10.1107/S0108768106041358

[14] Sahebalzamani, H., Khaligh, N., Ghammamy, S., Salimi, F. and Mehrani, K. (2011) Crystal Structure and Density Functional Theory Study on Structural Properties and Energies of an Isonicotinohydrazide Compound. Molecules, 16, 7715-7724. https://doi.org/10.3390/molecules16097715

[15] Yan, B., Zhang, G.-Q., Dang, D.-B., Ma, P.-T., Gao, H. and Niu, J.-Y. (2011) Assembly of Polyoxometalate-Based Inorganic-Organic Compounds from Silver-Schiff Base Building Blocks: Synthesis, Crystal Structures and Luminescent Prope. Crystal Engineering Communication, 13, 4181-4187. https://doi.org/10.1039/c1ce05192j

[16] Siddiqui, K.A. (2013) C-H... $\mathrm{O}_{\text {nitrate }}$ Synthon Assisted Molecular Assembly of Hydro- 
gen Bonded $\mathrm{Ni}(\mathrm{II})$ and $\mathrm{Cu}(\mathrm{II})$ Complexes. Journal of Coordination Chemistry, 66, 2039-2050. https://doi.org/10.1080/00958972.2013.797967

[17] Sheldrick, G.M. (2001) SHELXTL, Version 6.1. Bruker AXS, Inc. Madison, WI.

[18] Sheldrick, G.M. (1997) SHELXL97, Program for Crystal Structure Refinement, University of Gottingen, Gottingen.

[19] Sharma, K.K., Singh, R., Fahmi, N. and Singh, R.V. (2010) Synthesis, Coordination Behavior, and Investigations of Pharmacological Effects of Some Transition Metal Complexes with Isoniazid Schiff Bases. Journal of Coordination Chemistry, 63, 3071-3082. https://doi.org/10.1080/00958972.2010.504986

[20] Eldehna, W.M., Fares, M., Abdel-Aziz, M.M. and Abdel-Aziz, H.A. (2015) Design, Synthesis and Antitubercular Activity of Certain Nicotinic Acid Hydrazides. Molecules, 20, 8800-8815. https://doi.org/10.3390/molecules20058800 